Arctiin maddesinin lipopolisakkarit indüklü periodontal hastalık modeli üzerindeki antienflamatuvar etkinliğinin incelenmesi: Pilot çalışma

\section{Anti-inflammatory effects of arctiin in a rat model of lipopolysaccaharide- induced periodontal disease: A pilot study}

\author{
Uzm. Dr. Ahmet Aydoğdu \\ Bezmialem Vakıf Üniversitesi, Diş Hekimliği Fakültesi, \\ Periodontoloji A.D., İstanbul \\ Orcid ID: 0000-0002-1738-371X
}

Prof. Dr. Elif Eser Acarel

Ondokuz Mayıs Üniversitesi, Diş Hekimliği Fakültesi, Periodontoloji A.D., Samsun

Orcid ID: 0000-0002-3602-0877

Doç. Dr. Hasan Alaçam

Tıbbi Biyokimya, Ahenk Laboratuvarı, İstanbul

Orcid ID: 0000-0003-3807-2926

Geliș tarihi: 25 Aralık 2020

Kabul tarihi: 6 Mart 2021

doi: 10.5505/yeditepe.2021.05945

\section{Yazışma adresi:}

Dr. Ahmet Aydoğdu

Bezmialem Vakıf Üniversitesi Diş Hekimliği Fakültesi Periodontoloji Anabilim Dalı, İstanbul, Türkiye

Tel: +9021252322 88

Faks: +90 2125232288

E-posta: ahm0067@hotmail.com
ÖZET

Amaç: Arctiin maddesinin birçok dokuda enflamasyonu inhibe ettiği gösterilmiştir ancak bu etkilerin periodontal dokularda da olup olmadığı araştıııımamıștır. Bu çalışmanın amacı arctiin maddesinin periodontal hastalıklı rat gingival dokularında pro-enflamatuvar sitokin seviyelerinde bir azalmaya neden olup olmadığını incelemektir.

Gereç ve Yöntem: Çalışma 30 adet erkek Sprague-Dawley sıçan ile yapıldı. Deneysel periodontal hastalık, kontrol grubu $(n=10)$ hariç, sıçanların birinci ve ikinci sol maksiller azı dișleri arasına lipopolisakkarit (LPS) enjekte edilerek oluşturuldu. Deney gruptaki sıçanlar rastgele iki gruba ayrıldı (Grup DP: Deneysel plasebo-Dimetil sülfoksit (DMSO); Grup DA: Deneysel Arctiin, herbiri $n=10$ ). 21 gün boyunca günde bir kez ağızdan gavaj yapıldı. Daha sonra tüm hayvanlara ötenazi uygulandı, dişeti örnekleri alındı ve interleukin-1ß (IL-1 ß) ve tümör nekroz faktörü- a (TNF-a) ELISA ile analiz edildi.

Bulgular: Kontrol grubu, deney grupları (Grup DP ve DA) ile karşılaştırıldığında diş eti dokusuna, IL-1ß ve TNF-a seviyeleri kontrol grubunda istatistiksel olarak anlamlı düzeyde az bulundu $(P<0,001)$. DA grubu ise DP grubuna göre istatistiksel olarak daha düşük seviyelerde pro-enflamatuvar sitokin seviyeleri gösterdi $(P<0,001)$.

Sonuç: Arctiin maddesinin, LPS ile indüklenmiş periodontitisli sıçanların gingival dokularında proinflamatuar sitokin düzeylerini düşürdüğü gösterilmiştir.

Anahtar kelimeler: Arctiin, interleukin-1beta, tümör nekroz faktörü-alfa, lipopolisakkarit, periodontal hastalık

\section{SUMMARY}

Aim: Arctiin has been shown to inhibit inflammatory processes in various tissues, but its effects on periodontium have yet to be examined. Therefore, the aim of this study was to evaluate whether arctiin reduces pro-inflammatory cytokine levels in gingival tissues of rats with periodontal disease.

Materials and Method: The study was conducted with 30 male Sprague-Dawley rats. Experimental periodontal disease was induced by injecting lipopolysaccharide (LPS) between the first and second left maxillary molar teeth of rats, except control group $(n=10)$. Experimental rats were randomly divided into two groups (Group EP: Experimental placebo-Dimethyl sulphoxide (DMSO); Group EA: Experimental Arctiin, $\mathrm{n}=10$ each). Oral gavage carried out once per day for 21 days. All animals were then euthanized, gingival samples were obtained, and interleukin-1ß (IL-1ß) and tumor necrosis factor-a (TNF-a) were analysed by ELISA.

Results: Gingival tissue IL-1ß and TNF-a levels were significantly lower in the Control Group compared to both experimental groups $(E P$ and $E A)(P<0.001)$. EA group presented lower pro-inflammatory cytokine levels than those of non-arctiin treated placebo group $(\mathrm{P}<0.001)$.

Conclusion: Arctiin was shown to reduce pro-inflammatory cytokine levels in gingival tissues of rats with LPS-induced 
periodontitis.

Keywords: Arctiin; Interleukin-1beta; Tumor Necrosis Factor-alpha; lipopolysaccharide; periodontal disease

\section{Gíniş}

Periodontitis, periodonsiyumun yıkımına yol açan çok faktörlü, immün-enflamatuar ve kronik bir enfeksiyon olarak tanımlanmıştır. ${ }^{1-4}$ Periodontal hastalığın başlangıcı, mikrobiyal diş plağının varlığını gerektirse de, bu birincil etiyolojik faktöre karşı konakçı immün-inflamatuar yanıt, hastalığın ilerlemesinde ve şiddetinde daha büyük bir rol oynar. $^{3-6}$

Pro-enflamatuar sitokinlerin inhibisyonunun periodontal doku yıkımını sınırladığı gösterilmiştir. ${ }^{7-10}$ Çeşitli konak modülasyon stratejilerinden biri olan konak sitokin modülasyonu kapsamlı bir şekilde araştırılmıştır ve çalışmalar periodontal hastalığı tedavi etmek için kemoterapötik hedefler olarak sitokin ekspresyonu kaskadlarını göstermiştir. ${ }^{7-12}$ Bazı ilaçların konakçı sitokin ekspresyonunu inhibe ettiği bilinmektedir. Bununla birlikte, mevcut literatürdeki konak modülasyonu ilaçları, özellikle destekleyici periodontal tedavide gerekli olan uzun süreli kullanımdan ötürü bakteriyel direnç dahil çeşitli sistemik yan etkilere sahip olabilmektedir.,13,14 Bu durum araştırmacıları doğal bileşik ve ekstratları, alternatif terapötik seçenekler olarak incelemeye itmiştir., $75-19$

Yaygın olarak dulavratotu adıyla bilinen Arctium lappa birçok ülkede sebze olarak yetiştirilen ve tüketilen bir bitkidir. Geleneksel Kore tıbbında diüertik ve anti-enflamatuvar olarak kullanılır. ${ }^{20}$ Arctiium Lappa'dan elde edilen ilaçlar, geleneksel Çin Tıbbı' nda boğaz ağrısı, soğuk algınlığı, kabakulak, kızamık, açık yaralar, egzama ve hatta kanser tedavisi gibi geniş kullanım alanına sahiptir. ${ }^{20-22}$ Arctium Lappa bileşenleri birçok araştırmacı tarafından incelenmiş ve anti-karsinojenik ve anti-enflamatuvar özellikler ile pro-enflamatuvar sitokin üretimini baskılayan arctiin maddesi birincil bileşen olarak tespit edilmiştir. Arctiin maddesinin trombosit aktive edici faktörleri inhibe ettiği de bilinmektedir. ${ }^{20,23-29} \mathrm{Bu}$ madde periodontal hastalığın birçok safhasında önemli rol oynayan biyo-belirteçlerin baskılanmasını da sağlar. Nitrik oksitsit (NO) üretimini azaltması ve Nükleer Faktör-kB (NF-kB) sinyal yolunu inhibe ederek, prostaglandin-E2 (PGE2), interlökün-6 (IL-6), interlökin-1ß (IL-1ß) ve tümör nekrotize edici faktör- $a$

(TNF-a) ekspresyonlarını baskıladığı gösterilmiştir. ${ }^{20,27-29}$ Arctiin maddesinin periodontal hastalık üzerindeki etkileri bilinmediğinden çalışmamız bu konuyu araştırmayı amaçladı. Bu bitkisel ham maddenin etkilerini incelemek amacıyla lipopolisakkarit (LPS) indüklü sıçan periodontal hastalık modelini kullanarak diş eti dokusunda pro-enflamatuvar sitokin seviyelerini inceledik.

\section{GEREÇ VE YÖNTEM}

Çalışma Tasarımı ve Deneysel Periodontal Hastalık Protokolü
Çalışma, 100-117 g ağırlığındaki 30 erkek Sprague-Dawley albino sıçan üzerinde gerçekleştirildi. Sıçanlar, oda sıcaklığında $\left(22^{\circ} \mathrm{C} \pm 1^{\circ} \mathrm{C}\right)$ ve $\% 50$ nemde, 12:12 saat ışık: karanlık döngüsünde plastik kafeslerde ayrı ayrı barındırıldı ve uygun şekilde yiyecek ve su verildi. Tüm hayvan bakımı ve deneysel protokol, Hayvan Araştırmaları Etik Komitesi (Protokol No. 2012/06) tarafından onaylanan yönergelere uygun olarak yapıldı.

Sıçanlar rastgele olarak deneysel $(n=20)$ ve kontrol $(C)$ grubuna ( $n=10$ ) ayrıldı. Tüm sıçanlara 75-100 mg/kg ketamin-HCl ile anestezi uygulandı ve deneysel periodontal hastalık modeli, Porphyromonas gingivalis'den türetilen 1 $\mathrm{mg} / \mathrm{mL}$ lipopolisakkarit (LPS) (cat \# : tlr-pglps, Invivogen, San Diego, CA, ABD) içeren apirojen su (AS) çözeltisinin 10 uL'si birinci ve ikinci sol maksiller azı dişleri arasındaki palatal ve bukkal interdental papillaya enjekte edilerek indüklendi. 30 Bu işlem için 30 gauge iğne ucu olan olan bir insülin şırıngası kullanıldı (kat no: 328278 BD Company, New Jersey, ABD). Kontrol grubundaki sıçanlara, LPS içermeyen 10 uL AS enjekte edildi. Illk enjeksiyonları, 48 saatlik aralıklarla iki ek enjeksiyon izledi (Şekil 1).

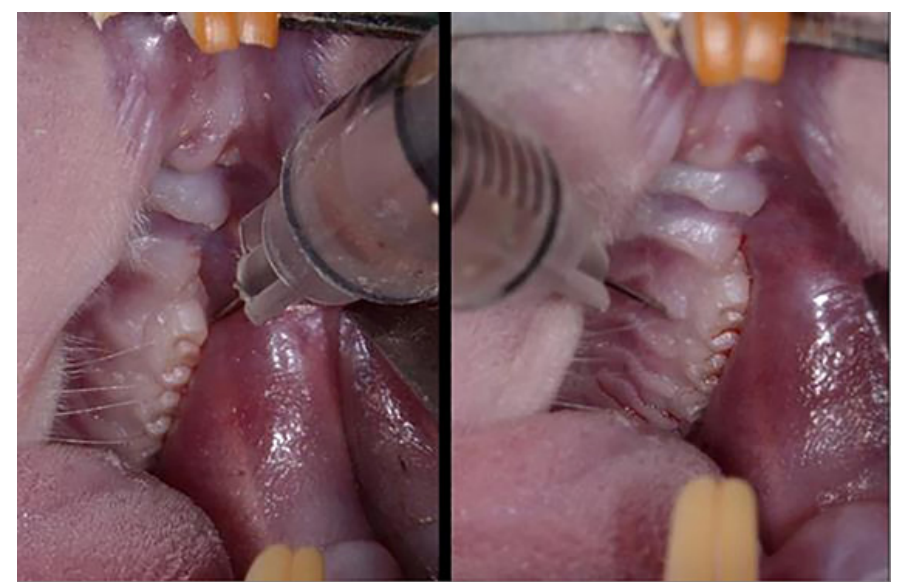

Sekil 1. Deneysel periodontal hastalığı indüklemek için uygulanan enjeksiyon prosedürü

Son enjeksiyondan yirmi dört gün sonra, periodontal hastalık oluşumu klinik (dişeti çekilmesi, dişeti iltihabı) ve radyolojik (kemik kaybı) (Şekil 2)

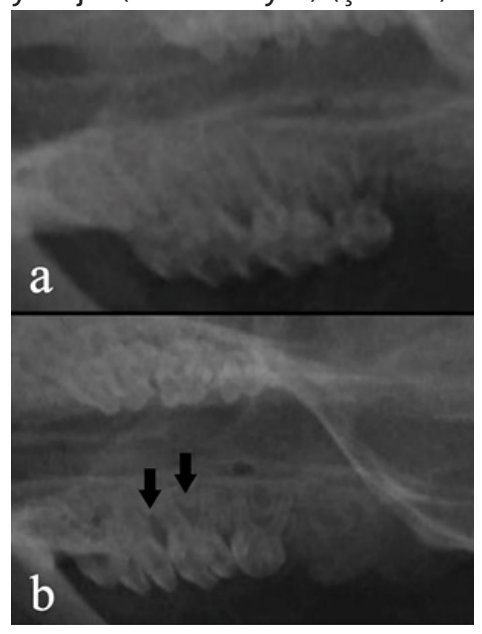

Şekil 2. Grupların radyografik görüntüleri (a: Kontrol grubu; b: Deneysel periodontitis grubu) 
(DP: Deneysel Plasebo; DA: Deneysel Arctiin, $n=10$, her biri). Kontrol ve DP grubuna, 21 gün boyunca gastrik gavaj ile, \% 0.1 dimetil sülfoksit çözeltisi verilirken (DMSO) (Kat \# 472301, Sigma-Aldrich, St. Louis, MO, ABD) ], DA grubuna $30 \mathrm{mg} / \mathrm{kg}$ DMSO' te çözülmüş saf arctiin (Kat \#: ALX-350-318-M025, Enzo Life Sciences, Inc., Farmingdale, NY, ABD) ] maddesi verildi. Test ve plasebo çözeltileri günde bir kez (öğleden sonra 3: 00-5: 00) uygulandı ve bunların sıçan ağırığına dayalı miktarları Tablo 1'de listelendi. Son uygulamadan on sekiz saat sonra, sıçanlara 75-100 mg/kg ketamin-HCl ile ötenazi uygulandı. Çalışma tasarımı Şekil 3'te özetlendi.

Tablo 1. Sıçan ağırlığına göre uygulanan + DMSO veya DMSO hacmi

\begin{tabular}{ccc}
$\begin{array}{c}\text { Sı̧̣an Ağırığı } \\
(\mathbf{g r})\end{array}$ & $\begin{array}{c}\text { Gerekli Arctiin Miktarı } \\
(\mathbf{m g})\end{array}$ & $\begin{array}{c}\text { Uygulanan Solüsyon Miktan } \\
(\mathbf{m l})\end{array}$ \\
\hline 100 & 3 & 0.6 \\
110 & 3.3 & 0.66 \\
120 & 3.6 & 0.72 \\
130 & 3.9 & 0.78 \\
140 & 4.2 & 0.84 \\
150 & 4.5 & 0.9 \\
160 & 4.8 & 0.96 \\
170 & 5.1 & 1.02 \\
180 & 5.4 & 1.08 \\
190 & 5.7 & 1.14 \\
\hline
\end{tabular}

Şekil 3. Çalışmanın akış şeması

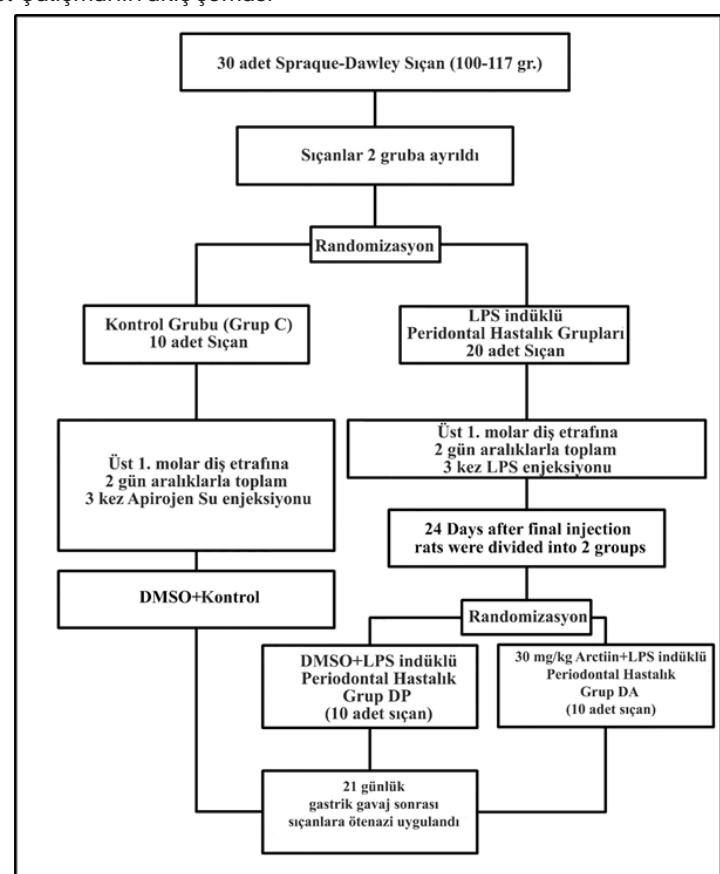

\section{Doku Örneklerinin elde edilmesi ve Biyokimyasal Analiz}

Dişleri çevreleyen bukkal ve palatinal dişeti dokuları eksize edildi, soğuk fizyolojik salin solüsyonu (\%0,9 sodyum klorür) ile yıkandı, fosfat tamponlu salin (PBS) $\left(4^{\circ} \mathrm{C} ; \mathrm{pH}\right.$ : 7,$4 ; 0.01 \mathrm{M} ; 0,7 \mathrm{~mL}$ ) içeren mikro tüplere yerleştirildi ve hemen dondurularak, biyokimyasal analiz gününe kadar -80 - $\mathrm{C}$ de saklandı. Örneklerden, Sakallıoğlu ve arkadaşları (2006) tarafından tarif edildiği şekilde homojenizasyon ve santrifügasyon işlemleri ile süpernantantlar elde edildi. ${ }^{31}$
Elde edilen homojenat 2 kere dondurulup çözüldükten sonra ultrasonikatörde $4-5 \mu \mathrm{m}^{\prime}$ de 10 saniye aralıklarla 30 saniye süresince 3 kere sonikasyona tabi tutuldu ve bunu takiben 10000 devir/dakika' da 10 dakika santrifüj edildi. Tüm bu uygulamalar $0-4^{\circ} \mathrm{C}^{\prime}$ de gerçekleştirildi.

Elde edilen süpernatantlardaki protein konsatrasyonu seviyesinin tayini için modifiye edilmiş protein tayin kiti üretici firma direktifleri doğrultusunda kullanıldı. (Modified Lowry Protein Assay Kit, Prod \# 23240, Thermo Scientific, Rockford, IL, ABD). Pro-enflamatuvar sitokin seviyelerinin belirlenmesi için ise sıçana özgü ELISA (Enzim illintili Immün Test) kitleri ticari firma direktifleri doğrultusunda kullanıldı. IL-1ß analizi (IL-1ß (rat), EIA kit, Catalog No. ADI900-131, Enzo Life Sciences Int inc., New York, ABD) ve TNF- $a$ analizi (TNF- $a$ (rat), ElA kit, Catalog No. ADI-900086A, Enzo Life Sciences Int inc., ABD) sonrası elde edilen spektrofotmetrik veriler kaydedilldi.

\section{İstatistiksel analiz}

İstatistiksel analiz SPSS, Sürüm 21 yazılımı kullanılarak gerçekleştirildi. Değişkenlerin normal dağılıma uygunluğu Kolmogorov-Simirnov ve Shapiro-Wilk's testleri ile doğrulandı. Normal dağıım gösteren parametreler için tanımlayıcı istatistikler ortalama ve standart sapma olarak verildi. Varyansların homojenliği Levene testi ile değerlendirildi ve gruplar arası karşılaştırmalar için tek yönlü ANOVA testi kullanıldı. Anlamlıık düzeyi $p<0,05$ olarak belirlendi. Gruplar arası ikili karşılaştırmalar için post-hoc Tukey testi kullanıldı. Parametreler arası ilişkileri belirlemek için ise Pearson Korelasyon testi kullanıldı.

\section{BULGULAR}

Tüm sıçanlar çalışmanın sonuna kadar hayatta kaldı. Başlangıçtaki sıçan ağırıkları gruplar arasında [Grup C $(109,03 \pm 4,89)$ / Grup DP ve DA $(108,35 \pm 4,46 \mathrm{~g})]$ anlamlı fark göstermedi. ( $p>0,05)$. Bunun yanında sıçan ağırlıkları çalışma sonunda da gruplar arasında [Grup C $(182,64 \pm 9.31 \mathrm{~g}) /$ Grup DP $(175,48 \pm 9,50 \mathrm{~g}) /$ Grup DA $(178,74 \pm 8,91 \mathrm{~g})]$ anlamlı farklılık göstermedi. $(p>0,05)$

\section{Biyokimyasal Analiz Bulguları}

TNF-a' nın konsantrasyonları ve protein miktarları aşağıdaki gibiydi: Grup C: $[108,72 \pm 28,52 \mathrm{pg} / \mathrm{mL}$ ve $81,19 \pm$ 16,33pg/mg protein]; Grup DP: [231,65 $\pm 63,11 \mathrm{pg} / \mathrm{mL}$ ve $242,29 \pm 20,41 \mathrm{pg} / \mathrm{mg}$ protein]; Grup DA: $[168,72 \pm 44,10$ $\mathrm{pg} / \mathrm{mL}$ ve $130,12 \pm 20,25 \mathrm{pg} / \mathrm{mg}$ protein]. Gruplar arasında TNF-a konsantrasyonu ve protein miktarları açısından anlamlı fark görüldü $(p<0,05)$. ikili grup karşılaştırmalarında, TNF-a konsantrasyonları ve protein miktarları açısından gruplar arasındaki farkları ise sırasıyla şu şekildeydi; konsantrasyonlar [(Grup C/Grup DP, p=0,000; Grup C/ Grup DA, $p=0,038$; Grup DP/Grup DA $p=0,000$ )] ve protein miktarları [Grup C/Grup DP, $p=0,000$; Grup C/Grup DA, $p=0,001 ;$ Grup DP/Grup DA, $p=0,006$ )] (Tablo 2). 
Tablo 2. Parametrelerin gruplar arası dağılımı ve istatistiksel analiz.

\begin{tabular}{|c|c|c|c|}
\hline & $\begin{array}{c}\text { Grup C } \\
\mathrm{N}=10 \\
+, \pm\end{array}$ & $\begin{array}{c}\text { Grup DP } \\
\mathrm{N}=10 \\
\dagger,\end{array}$ & $\begin{array}{c}\text { Grup DA } \\
\mathrm{N}=10 \\
+,\end{array}$ \\
\hline $\begin{array}{c}\text { TNF- } \alpha \\
(\mathrm{pg} / \mathrm{mL})\end{array}$ & $\begin{array}{c}108.72+28.52^{a(+\infty),} \\
b(c)\end{array}$ & $\left.231.65 \pm 63.111^{(-\infty)}, \mathrm{c}^{+\infty}\right)$ & $168.72 \pm 44.10^{\mathrm{b}()^{-2}, \mathrm{e}(\%)}$ \\
\hline $\begin{array}{c}\text { TNF- } \alpha \\
\text { (pg/mg protein) }\end{array}$ & 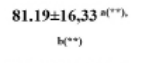 & $242.29 \pm 20.41$ (स"*), & $130.12 \pm 20.25^{\mathrm{b}\left(\mathrm{e}^{*}, \mathrm{e}, \mathrm{Cu}\right.}$ \\
\hline $\begin{array}{c}\mathrm{IL}-1 \mathrm{~B} \\
(\mathrm{pg} / \mathrm{mL})\end{array}$ & 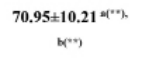 & $117,03 \pm 16,44 \times\left(\mathrm{x}_{3} \mathrm{ec}\right)$ & $95.82 \pm 1.43^{b(-m), e(-)}$ \\
\hline $\begin{array}{c}\text { IL-1B } \\
\text { (pg/mg protein) } \\
\text { Protein }\end{array}$ & $53.69 \pm 7.29$ (c), b(c) & $127.33 \pm 27.59$ ("("), ce(") & $74.95 \pm 10.75^{\left.\mathrm{b}(7), \mathrm{e}()^{-*}\right)}$ \\
\hline $\begin{array}{c}\text { Concentration } \\
\text { (mg/mL) }\end{array}$ & $1.35 \pm 0.27 \mathrm{~b}^{-9}$ & $0.97 \pm 0.34^{(b-9)}$ & $1.31 \pm 0.31^{(\cdots-\cdot)}$ \\
\hline
\end{tabular}

$=$ One-Way ANOVA testi

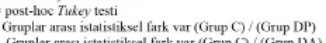

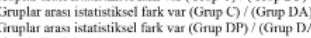

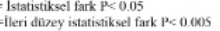

=-leri dizey islatistiksel fark $P<0.006$

IL-1ß konsantrasyonları ve protein miktarları aşağıdaki

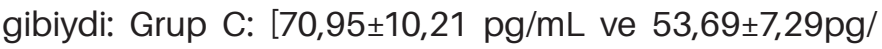
mg protein]; Grup DP: $[117,03 \pm 16,44 \mathrm{pg} / \mathrm{mL}$ ve $127,33 \pm 27,59 \mathrm{pg} / \mathrm{mg}$ protein]; Grup DA: [95,85 $\pm 1,43 \mathrm{pg} /$ $\mathrm{mL}$ ve $74,95 \pm 10,75 \mathrm{pg} / \mathrm{mg}$ protein]. Gruplar arasında IL-1ß konsantrasyonu ve protein miktarları açısından anlamlı fark görüldü $(p<0,05)$. İkili grup karşılaştırmalarında, IL-1ß konsantrasyonları ve protein miktarları açısından gruplar arasındaki farkları ise sırasıyla şu şekildeydi; konsantrasyonlar [(Grup C/Grup DP, $\mathrm{p}=0,000$; Grup C/Grup DA, $p=0.000$; Grup DP/Grup DA, $p=0.000)$ ] ve protein miktarları [Grup C/Grup DP, $p=0,000$; Grup C/Grup DA, $p=0,028$; Grup DP/Grup DA, p=0,021)] (Tablo 2).

Protein konsantrasyonları aşağıdaki gibiydi: Grup C: [1,35 $\pm 0,27 \mathrm{mg} / \mathrm{mL}]$; Grup DP: $[0,97 \pm 0,34 \mathrm{mg} / \mathrm{mL}]$; Grup DA: [1,31 $\pm 0,31 \mathrm{mg} / \mathrm{mL}$. Grup C ve Grup DP arasında protein konsantrasyonu açısından istatistiksel olarak anlamlı fark ( $p=0,031)$ olmasına rağmen; hem Grup C ve Grup DA ( $p=0,973)$ hem de Grup DP ve Grup DA $(0,059)$ karşılaştırmalarında istatistiksel olarak anlamlı fark bulunmadı.

Hem TNF-a ve IL-1ß konsantrasyonları hem de TNF-a ve IL-1ß miktarları arasında pozitif bir korelasyon olduğu görüldü $(p<0,005)$. Doku protein konsantrasyonları ile TNF-a ve IL-1ß konsantrasyonları arasında istatistiksel olarak anlamlı bir ilişki bulunmazken ( $p>0,05)$; doku protein konsantrasyonu ile TNF- $a$ ve IL-1ß protein miktarları arasında önemli bir korelasyon vardı $(p<0,05)$. (Tablo 3 )

Tablo 3. Parametrelerin korelasyon matriksi.

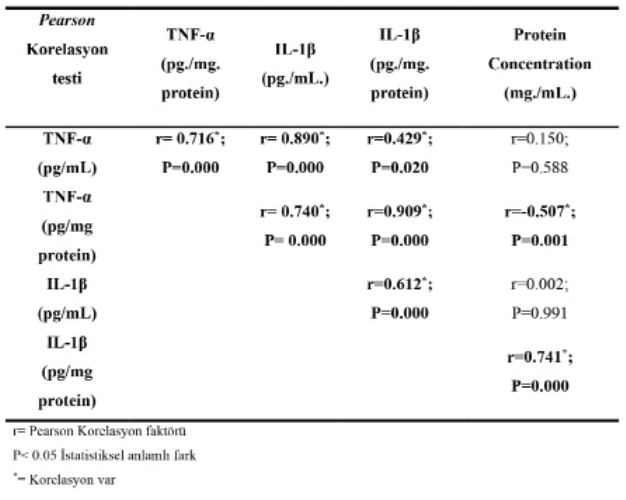

\section{TARTIŞMA}

Periodontal hastalığın gelişimi TNF-ave IL-1ß gibi pro-enflamatuvar sitokinlerinin artışı ile karakterizedir. Bu sitokinler hücre yüzeylerindeki reseptörlere bağlanarak konak yanıtının başlamasına ve dolayısıyla katabolik aktivitelerin tetiklenmesine neden olabilirler. ${ }^{7}$ Çalışmalara periodontal hastalığın şiddetindeki artışla beraber bu sitokinlerin de arttığını göstermiştir. Enflamatuvar dokularda homeostaz mikroorganizmalar, konak savunma mekanizmaları ve çevresel faktörler ile ilgili uyaranların yıkıcı etkilerini baskılayarak veya azaltarak sağlanabilir. ${ }^{32}$ Konak-beakteri etkileşimine bağlı periodontal yıkımın konak yanıtı inhibe edilerek azaltılabileceği bilinmektedir. Peridontal hastalığın patogenezinin daha iyi anlaşılması ile beraber periodontal tedaviye ek olarak farmakolojik konak yanıtı inhibisyonunun tedaviye katkı sağlayabileceği

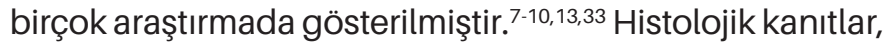
pro-enflamatuar sitokin (TNF-a ve IL-1ß) antagonistlerinin deneysel periodontitis modelinde periodontal doku kaybını azalttığını göstermiştir. ${ }^{34-36}$

Bu çalışma TNF- $a$ ve IL-1ß ekspresyonunu inhibe ederek enflamasyonu azaltma potansiyeline sahip arctiin maddesinin lipopolisakkarit (LPS) indüklü periodontal hastalık modelindeki etkilerinin incelendiği ilk çalışma olması nedeni ile önem arz etmektedir.

Wu ve ark. (2009) arctiin maddesinin anti-enflamatuvar etkilerini inceledikleri çalışmalarında maddenin 3 hafta boyunca sistemik olarak uygulanmasın takiben doza $(30,60,120 \mathrm{mg} / \mathrm{kg})$ bağlı şekilde serum IL-6 ve TNF-a seviyelerini anlamlı şekilde azalttığını göstermişlerdir. Bu çalışmanın sonuçları göz önünde bulundurularak biz de çalışmamızda kullanılan arctiin dozunun 30 mg/kg olmasına karar verdik. ${ }^{29}$

Arctiin maddesinin absorbsiyonunun erkek ve dişi sıçanlar arasında farklılık gösterdiği, dişi sıçanlarda arctiin absorbsiyonunun daha hızlı, eleminasyonunun ise erkek sıçanlara göre daha yavaş olduğu gösterilmiştir. Bu farklılığın arctiin maddesinin östrojen benzeri etkiler göstermesinden kaynaklandığı düşünülmektedir. ${ }^{37} \mathrm{Bu}$ sebepten ötürü çalışmamızda erkek sıçanlar tercih edilmiştir.

Arctiin maddesinin anti-enflamatuvar etkilerini inceleyebilmek için çalışmamızda P. gingivalis-LPS İndüklü periodontal hastalık modeli kullanılmıştır. ${ }^{30}$ Belirli bir bölgeye yapılan bakteriyel LPS enjeksiyonunun doğrudan ve kontrollü bir periodoontal hastalık modeli olduğu düşünülmektedir. Bunun nedeni hastalığın bilinen bir periodonto patojenin virülan faktörü ile indüklenmesi, enfeksiyon süresinin kesin olması ve uyaranın sabit olması olarak açıklanmaktadır. ${ }^{38}$ Deneysel periodontitis aşaması 4 ila 8 haftalık bir süreç gerektirmektedir. ${ }^{39-41}$ Tekrarlayan enjeksiyonların ( 1 hafta içerisinde 2 veya 3 
kez) genel anestezi altında yapılıyor olması bu model için bir dezavantaj olarak bildirilmiştir. ${ }^{39-42} \mathrm{P}$. gingivalis LPS' inin ise TNF- $a$ ve IL-1ß sitokinlerinin ekspresyonunu arttırdığı gösterilmiştir. ${ }^{43,44}$

Lee ve ark. (2007) yaptıkları çalışmalarında nitrik oksit sentetaz (iNOS), TNF-a ve NO üretimini, p38 MAP kinaz/ NF-kB yolunu baskılayarak, azaltan arctiin maddesinin birçok enflamatuvar hastalığın tedavisine katkı sağlayabileceğini bildirmişlerdir. ${ }^{24}$

Yapılan başka bir deneysel hayvan çalışmasında albümin indüklü glomerülonefrite bağlı artan kan biyo belirteçlerinde üç haftalık arctiin tedavisinin ardından doza $(30,60,120 \mathrm{mg} / \mathrm{kg})$ bağlı şekilde önemli ölçüde iyileşme gözlendiği gösterilmiştir.Araştırmacılar arctiin maddesinin NF-kB inhibitörü olarak enflamatuvar hastalıkların klinik tedavisinde kullanılma potansiyelinin olduğu görüşüne varmışlardır. ${ }^{29}$

Lee ve ark. (2011) yaptıkları in-vitro çalışmada arctiin maddesinin NO, prostoglandin-E2 (PGE-2),IL-1ß,

TNF- $a$ ve IL-6 seviyelerinde doza bağlı şekilde ve NF-kB inaktivasyonu yolu ile azalmaya sebep olduğunu göstermişlerdir. ${ }^{25}$ Bizim çalışmamızda, arctiin maddesi verilen grupta dişeti IL-1ß ve TNF-a seviyeleri, arctiin maddesi verilmeyen gruba göre daha düşük bulunmuştur. Histolojik olarak doğrulanmamış olsa da arctiin maddesinin deneysel periodontal hastalık modelinde dişetindeki enflamatuvar yanıtı azalttığı biyokimyasal olarak gösterilmiştir. Bu açıdan bakıldığında çalışma bulguları yukarıda bahsedilen çalışmalar ile uyum göstermektedir. Diğer yandan arctiin verilen periodontal hastalık grubundaki sıçanlarda TNF-a ve IL-1ß konsantrasyon ve miktarlarının periodontal sağlıklı gruba göre daha yüksek olması, diğer periodontal tedaviye yardımcı ajanlar gibi arctiin maddesinin de tek başına periodontal hastalık tedavisinde başarı sağlayamayacağını düşündürmektedir.

Arctiin maddesi ve metaboliti olan arctigenin maddesinin farklı zamanlarda plazmada ve sıçanların sakrifiye edildikleri günde dişetindeki miktarları ve konsantrasyonlarının incelenmemiş olması bu çalışmanın limitasyonları arasındadır. Eğer bu yapılabilmiş olsa idi pro-enflamatuvar sitokin seviyeleri ve dokulardaki arctiin/arctigenin seviyeleri arasında bir ikilişki kurulabilirdi.

Fan ve ark. ${ }^{37}$ arctiin maddesinin oral uygulaması sonrasında, arctiin ve metaboliti arctigenin maddesinin tüm organlara hızla yayıldığını belirtmişlerdir. Dalakta uygulamadan 30 dakika sonra arctiin konsantrasyonunun en fazla olduğu, bunu sırayla karaciğer, kalp, ince barsak, mide, akciğerler ve böbrek dokularının izlediği gösterilmiştir. Bunun yanından uygulamadan üç saat sonra her iki maddenin konsantrasyonunun da özellikle dalakta büyük ölçüde azaldığı bildirilmiştir. ${ }^{37}$

SONUÇ

Arctiin maddesinin periodontal doku harabiyetine yol açan pro-enflamatuvar sitokkin seviyelerini düşürme üzerine olumlu etkilerininin olabileceği sonucuna varılabilir. Bununla birlikte, arctiin maddesinin periodontal tedavi sırasında ve hatta periodontal hastalığın önlenmesi üzerine etkilerinin araştırıldığı daha fazla sayıda çalışmaya ihtiyaç vardır.

\section{Teşekkürler ve Çıkar Çatışması}

Bu çalışma, Samsun Ondokuz Mayıs Üniversitesi Bilimsel Araştırmalar Proje Yönetim Ofisi tarafından desteklenmiştir (Proje numarası: PYO.DIS.1904.12.010). Yazarlar, bu çalışmada yer alan herhangi bir ürünle ilgili finansal ilişkileri olmadığını beyan ederler.

\section{KAYNAKLAR}

1. Armitage GC. Development of a classification system for periodontal diseases and conditions. Annals of Periodontol 1999;4:1-6.

2. $\mathrm{CHO}$ MI, Garant PR. Development and general structure of the periodontium. Periodontol 2000. 2000;24:927.

3. Page R. Current understanding of the aetiology and progression of periodontal disease. Int Dent J 1986;36:153161.

4. Socransky S, Haffajee A, Cugini M, Smith C, Kent Jr R. Microbial complexes in subgingival plaque. J Clin Periodontol 1998;25:134-144.

5. Reddy MS, Geurs NC, Jeffcoat RL, Proskin H, Jeffcoat MK. Periodontal Disease Progression. J Periodontol 2000;71:1583-1590.

6. Schenkein HA. Host responses in maintaining periodontal health and determining periodontal disease. Periodontol 2000 2006;40:77-93.

7. Kantarci A, Hasturk H, Van Dyke TE. Host-mediated resolution of inflammation in periodontal diseases. Periodontol 2000 2006;40:144-163.

8. Kirkwood KL, Cirelli JA, Rogers JE, Giannobile WV. Novel host response therapeutic approaches to treat periodontal diseases. Periodontol 2000 2007;43:294-315.

9. Offenbacher S. Periodontal diseases: pathogenesis. Ann Periodontol 1996;1:821-878.

10. Souza JACd, Junior CR, Garlet GP, Nogueira AVB, Cirelli JA. Modulation of host cell signaling pathways as a therapeutic approach in periodontal disease. Journal of Applied Oral Science 2012;20:128-138.

11. Gemmell E, Marshall RI, Seymour GJ. Cytokines and prostaglandins in immune homeostasis and tissue destruction in periodontal disease. Periodontology 2000 1997; 14:112-143.

12. Lamster IB, Novak MJ. Host mediators in gingival crevicular fluid: implications for the pathogenesis of periodontal disease. Crit Rev Oral Biol Med 1992;3:31-60.

13. Okada H, Murakami S. Cytokine expression in peri- 
odontal health and disease. Crit Rev Oral Biol Med 1998;9:248-266.

14. Salvi G, Lang N. The effects of non-steroidal anti-inflammatory drugs (selective and non-selective) on the treatment of periodontal diseases. Curr Pharm Des 2005; 11:1757-1769.

15. Botelho M, Rao V, Carvalho C, Bezerra-Filho J, Fonseca $S$, et al. Lippia sidoides and Myracrodruon urundeuva gel prevents alveolar bone resorption in experimental periodontitis in rats. J Ethnopharmacol 2007;113:471478.

16. Cao CF, Sun XP. Herbal medicine for periodontal diseases. Int Dent J 1998;48:316-321.

17. Chan $\mathrm{Y}$, Lai $\mathrm{C}-\mathrm{H}$, Yang $\mathrm{H}-\mathrm{W}$, Lin $\mathrm{Y}-\mathrm{Y}$, Chan $\mathrm{C}-\mathrm{H}$. The evaluation of Chinese herbal medicine effectiveness on periodontal pathogens. The Am J Chinese Med 2003;31:751-761.

18. Sastravaha G, Gassmann G, Sangtherapitikul $P$, Grimm W-D. Adjunctive periodontal treatment with Centella asiatica and Punica granatum extracts in supportive periodontal therapy. J Int Acad Periodontol 2005;7:7079.

19. Shannon J, Shannon J, Modelevsky S, Grippo AA. Bisphosphonates and osteonecrosis of the jaw. J Am Geriatr Soc 2011;59:2350-2355.

20. Park SY, Hong SS, Han XH, Hwang JS, Lee D, et al. Lignans from Arctium lappa and their inhibition of LPS-induced nitric oxide production. Chem Pharm Bull (Tokyo). 2007;55:150-152.

21. Chan Y-S, Cheng L-N, Wu J-H, Chan E, Kwan Y-W, et al. A review of the pharmacological effects of Arctium lappa (burdock). Inflammopharmacol 2011;19:245-254.

22. Lin C-C, Lin J-M, Yang J-J, Chuang S-C, Ujiie T. Anti-inflammatory and radical scavenge effects of Arctium lappa. The Am J Chinese Med 1996;24:127-137.

23. Guo M, Liang J, Wu S. On-line coupling of counter-current chromatography and macroporous resin chromatography for continuous isolation of arctiin from the fruit of Arctium lappa L. J Chromatogr A 2010;1217:5398-5406.

24. Lee $M H$, Lee JM, Jun SH, Ha CG, Lee SH, et al. In-vitro and in-vivo anti-inflammatory action of the ethanol extract of Trachelospermi caulis. J Pharm Pharmacol 2007;59:123-130.

25. Lee S, Shin S, Kim H, Han S, Kim K, et al. Anti-inflammatory function of arctiin by inhibiting COX-2 expression via NF-1B pathways. J Inflamm 2011;8:16.

26. Liu $H$, Zhang Y, Sun $Y$, Wang $X$, Zhai Y, et al. Determination of the major constituents in fruit of Arctium lappa $L$. by matrix solid-phase dispersion extraction coupled with HPLC separation and fluorescence detection. J Chromatography B 2010;878:2707-2711.

27. Liu S, Chen K, Schliemann W, Strack D. Isolation and identification of arctiin and arctigenin in leaves of burdock (Arctium lappa L.) by polyamide column chromatography in combination with HPLC-ESI [sol] MS. Phytochemical Analysis: Int J Plant Chem BiochemTech 2005; 16:86-89.

28. Matsuzaki $Y$, Koyama M, Hitomi T, Yokota $T$, Kawanaka $\mathrm{M}$, et al. Arctiin induces cell growth inhibition through the down-regulation of cyclin D1 expression. Oncol Rep 2008;19:721-727.

29. Wu J-G, Wu J-Z, Sun L-N, Han T, Du J, et al. Ameliorative effects of arctiin from Arctium lappa on experimental glomerulonephritis in rats. Phytomedicine 2009; 16:10331041.

30. Kador PF, O'Meara JD, Blessing K, Marx DB, Reinhardt RA. Efficacy of structurally diverse aldose reductase inhibitors on experimental periodontitis in rats. $J$ Periodontol 2011;82:926-933.

31. Sakallıoğlu EE, Ayas B, Sakallıoğlu U, Açıkgöz G, Çağlayan F. Osmotic pressure and vasculature of gingiva in periodontal disease: an experimental study in rats. Arch Oral Biol 2006;51:505-511.

32. Genco CA, Van Dyke T, Amar S. Animal models for Porphyromonas gingivalis-mediated periodontal disease. Trends Microbiol 1998;6:444-449.

33. Paquette DW, Williams RC. Modulation of host inflammatory mediators as a treatment strategy for periodontal diseases. Periodontol 2000 2000;24:239-252.

34. Delima A, Oates $T$, Assuma R, Schwartz Z, Cochran $D$, et al. Soluble antagonists to interleukin-1 (IL-1) and tumor necrosis factor (TNF) inhibits loss of tissue attachment in experimental periodontitis. J Clin Periodontol 2001;28:233-240.

35. Delima AJ, Karatzas S, Amar S, Graves DT. Inflammation and tissue loss caused by periodontal pathogens is reduced by interleukin-1 antagonists. J Infec Diseases 2002;186:511-516.

36. Oates $T$, Graves $D$, Cochran DL. Clinical, radiographic and biochemical assessment of IL-1/TNF- $a$ antagonist inhibition of bone loss in experimental periodontitis. J Clin Periodontol 2002;29:137-143.

37. Fan $H$, De-Qiang $D$, Yu S, Ting-Guo K. Determination of Arctiin in rat plasma by HPLC method and its application to pharmacokinetic studies. J Med Plants Res 2011;5:549-557.

38. de Molon RS, de Avila ED, Cirelli JA. Host responses induced by different animal models of periodontal disease: a literature review. J Invest Clin Dent 2013;4:211218.

39. Rogers JE, Li F, Coatney DD, Rossa Jr C, Bronson P, et al. Actinobacillus actinomycetemcomitans lipopolysaccharide-mediated experimental bone loss model for aggressive periodontitis. J Periodontol 2007;78:550-558. 40. de Aquino SG, Guimaraes MR, Stach-Machado DR, da Silva JAF, Spolidorio LC, et al. Differential regulation 
of MMP-13 expression in two models of experimentally induced periodontal disease in rats. Arch Oral Biol 2009;54:609-617.

41. de Aquino SG, Leite FRM, Stach-Machado DR, da Silva JAF, Spolidorio LC, et al. Signaling pathways associated with the expression of inflammatory mediators activated during the course of two models of experimental periodontitis. Life Sci 2009;84:745-754.

42. Genco RJ. Host responses in periodontal diseases: current concepts. J Periodontol 1992;63:338-355.

43. Sugita N, Kimura A, Matsuki Y, Yamamoto T, Yoshie $H$, et al. Activation of transcription factors and IL-8 expression in neutrophils stimulated with lipopolysaccharide from Porphyromonas gingivalis. Inflam 1998;22:253-267. 44. Yoshimura A, Hara $Y$, Kaneko T, Kato I. Secretion of IL-1, TNF- $\mathrm{a}$ IL-8 and IL-1 ra by human polymorphonuclear leukocytes in response to lipopolysaccharides from periodontopathic bacteria. J Periodon Res 1997;32:279-286. 